Research Article

\title{
French Fries-Like Bismuth Oxide: Physicochemical Properties, Electrical Conductivity and Photocatalytic Activity
}

\author{
Yayuk Astuti ${ }^{1, *}$, Fauzan Musthafa ${ }^{1}$, A. Arnelli ${ }^{1}$, Iis Nurhasanah ${ }^{2}$ \\ ${ }^{1}$ Chemistry Department, Faculty of Natural Sciences and Mathematics, Diponegoro University, \\ Jalan Prof. Soedarto, Tembalang, Semarang, Indonesia. \\ ${ }^{2}$ Physics Department, Faculty of Natural Sciences and Mathematics, Diponegoro University, \\ Jalan Prof. Soedarto, Tembalang, Semarang, Indonesia.
}

Received: 22 ${ }^{\text {nd }}$ October 2021; Revised: $6^{\text {th }}$ December 2021; Accepted: $7^{\text {th }}$ December 2021 Available online: 15th December 2021; Published regularly: March 2022

\section{Abstract}

Bismuth oxide synthesis using hydrothermal method has been conducted. This study aims to examine the effect of the hydrothermal reaction time on product characteristics and photocatalytic activity in degrading methyl orange dye. Bismuth oxide synthesis was initiated by dissolving bismuth nitrate pentahydrate $\left(\mathrm{Bi}\left(\mathrm{NO}_{3}\right)_{3} .5 \mathrm{H}_{2} \mathrm{O}\right)$ and $\mathrm{Na}_{2} \mathrm{SO}_{4}$ in distilled water and added $\mathrm{NaOH}$ gradually. The solution formed was transferred into a Teflon-lined autoclave and heated at $120^{\circ} \mathrm{C}$ with time variations of $8-16$ $\mathrm{h}$. The formation of bismuth oxide was indicated by the vibrations of the $\mathrm{Bi}-\mathrm{O}-\mathrm{Bi}$ and $\mathrm{Bi}-\mathrm{O}$ groups and the crystal structure consisting of $\alpha-\mathrm{Bi}_{2} \mathrm{O}_{3}, \beta-\mathrm{Bi}_{2} \mathrm{O}_{3}$, and $\gamma-\mathrm{Bi}_{2} \mathrm{O}_{3}$. In addition, the highest photocatalytic activity can be examined through several factors, such as: content of $\mathrm{Bi}-\mathrm{O}-\mathrm{Bi}$ and $\mathrm{Bi}-\mathrm{OH}$ groups, crystal structure, band gap values, morphology, and surface area, acquired as a result of the effect of hydrothermal reaction time.

Copyright ( $\odot 2021$ by Authors, Published by BCREC Group. This is an open access article under the CC BY-SA License (https://creativecommons.org/licenses/by-sa/4.0).

Keywords: Bismuth Oxide; $\mathrm{Bi}_{2} \mathrm{O}_{3}$; Semiconductor; Hydrothermal; Photocatalysis

How to Cite: Y. Astuti, F. Musthafa, A. Arnelli, I. Nurhasanah (2022). Study French Fries-Like Bismuth Oxide: Physicochemical Properties, Electrical Conductivity and Photocatalytic Activity. Bulletin of Chemical Reaction Engineering \& Catalysis, 17(1), 146-156 (doi: 10.9767/bcrec.17.1.12554.146-156)

Permalink/DOI: https://doi.org/10.9767/bcrec.17.1.12554.146-156

\section{Introduction}

Bismuth oxide exhibits several useful properties, two of which are photocatalytic and electrochemical activities. Photocatalysis combines photochemical processes and catalysis in one framework, that is, chemical degradation processes that involve light as a trigger and a cata-

\footnotetext{
* Corresponding Author.

Email: yayuk.astuti@live.undip.ac.id (Y. Astuti);

Telp.: (024) 7474754
}

lyst as an accelerator of the transformation processes therein [1]. Meanwhile, bismuth oxide is also found to be potential as battery anode which could be attributed to large specific capacity, good electrical and optical properties with a bandgap of $2.8 \mathrm{eV}$, and a potential difference of 1.75-2.25 V [2]. Both potential properties are influenced by physicochemical characteristics of materials, such as crystal structure, morphology, functional group, band gap, which depend on material fabrication [3-6]. 
Some of the experimental investigations and preparation processes have demonstrated the strong correlation between the synthesis procedure of $\mathrm{Bi}_{2} \mathrm{O}_{3}$ and its photo-catalytic activities [7]. The different methods and experimental conditions of synthesis result in production of different size, morphology, crystal structure and band gap of the resulting materials affecting the material's photocatalytic activity $[8,9]$ and other properties, such as electrochemical behavior [10].

Synthesis of bismuth oxide can be conducted by several methods including precipitation [5,11], sol-gel [6], solution combustion $[4,12,13]$ and hydrothermal [14-17]. In this study, the hydrothermal method was applied to produce bismuth oxide since it has several advantages, such as: precipitant-free, additive-free, no need sophisticated equipment, and low temperature processing, which lead to energy saving and cost effective [14-18]. Moreover, controllable particle size, morphology and the degree of crystallinity of the resulting products can be achieved [14]. The factors that affect the synthesized products in this method include temperature, pressure, and hydrothermal process time. The heat produced by water in the hydrothermal method provides a vapor pressure that plays a role in crystal formation. Several studies have studied bismuth oxide synthesized by hydrothermal method [14-19]. However, the overall properties of the resulting products, such as: crystal structure, morphology, purity, band gap, electrical properties and photocatalytic activity, have not been fully studied comprehensively. Taking these accounts, the present research delves into the synthesis of bismuth oxide using the hydrothermal method and investigate physicochemical properties, electrical conductivity, and photocatalytic activity.

Bismuth oxide is a potential material for a photocatalyst and has been applied to degrade dye molecules, such as methyl orange, remazol black B (RBB) and rhodamine B (RhB) $[4,13,20,21]$. Industries, such as printing, textiles, cosmetics and papers, are inseparable from the use of dyes, especially synthetic dyes $[22,23]$. These dyes have persistent stability to chemical substances, heat and light and are endowed with prolonged endurance in the environment. Because of their nature, the industrial waste produced is practically harmful to aquatic environments and interferes with light penetration in the receiving water bodies resulting in disturbing the biological processes $[22,23]$. Therefore, it is necessary to remove toxic dyes before discharging them into the en- vironment which can be undertaken by oxidation processes (AOPs) based on the oxidation through reaction with hydroxyl radicals $(\cdot \mathrm{OH})$. Photocatalysis has been established as an effective advanced oxidation process [24] and of great interest due to efficiency, environmentally-friendly and high-throughput properties [25].

\section{Materials and Methods}

\subsection{Materials}

The materials used in this study were bismuth nitrate pentahydrate $\left(\mathrm{Bi}\left(\mathrm{NO}_{3}\right)_{3} .5 \mathrm{H}_{2} \mathrm{O}\right)$ from Sigma-Aldrich. Other reagents used were sodium sulfate $\left(\mathrm{Na}_{2} \mathrm{SO}_{4}\right)$, sodium hydroxide $(\mathrm{NaOH})$, and methyl orange bought from Merck, Indonesia. Moreover, distilled water was also used.

\subsection{Bismuth Oxide Synthesis}

The synthesis of bismuth oxide was done using the hydrothermal method. The synthesis was initiated by adding $40 \mathrm{~mL}$ of distilled water into a beaker containing $8 \mathrm{mmol}$ $\mathrm{Bi}\left(\mathrm{NO}_{3}\right)_{3} .5 \mathrm{H}_{2} \mathrm{O}$ and $12 \mathrm{mmol} \mathrm{Na}_{2} \mathrm{SO}_{4}$, which was then stirred using a magnetic stirrer for 45 minutes. Subsequently, $72 \mathrm{mmol}$ of $\mathrm{NaOH}$ was dissolved in $40 \mathrm{~mL}$ of distilled water and was added gradually into the previous solution. Once homogenous, the mixture was transferred into the Teflon-lined autoclave (a hydrothermal reactor) and heated at a temperature of $120^{\circ} \mathrm{C}$ with time variations of $8,10,12,14$, and $16 \mathrm{~h}$. The mixture was then cooled to room temperature. The precipitate obtained was washed using distilled water, then dried at $80^{\circ} \mathrm{C}$.

\subsection{Material Characterizations}

The powders obtained from the synthesis were characterized using X-ray diffraction, (XRD), Fourier transform - infra red (FT-IR), scanning electron microscopy (SEM), and UVvis diffuse reflectance spectroscopy (DRS) instruments. The crystal structure of the bismuth oxide synthesized was analyzed using the XRD Shimadzu 7000. Infrared spectroscopic analysis was carried out using the Shimadzu IRAffinity-1 FTIR in the wavenumber range of $500-4500 \mathrm{~cm}^{-1}$ to determine the functional groups present in the synthesized products. The morphology of the synthesized bismuth oxide was seen using SEM JEOL JED 6510LA with magnifications of 1000 and 5000 times. Pharmaspec UV-DRS UV 1700 analysis was performed to calculate the bandgap of the synthesized bismuth oxide. These characteriza- 
tions also aimed to identify the purity of the obtained products. Moreover, electrical conductivity property was identified using LCR meter.

\subsection{Photocatalytic Activity Test}

In this photocatalytic test, a methyl orange stock solution of $1000 \mathrm{ppm}$ was first made by dissolving 0.1 gram of methyl orange in $100 \mathrm{~mL}$ of distilled water. From that, methyl orange solution was made for photocatalysis. This solution was analyzed using a UV-Vis spectrophotometer to determine the maximum wavelength of the methyl orange. A series of standard solutions of $6 \mathrm{ppm}, 5 \mathrm{ppm}, 4 \mathrm{ppm}, 3 \mathrm{ppm}$, and $2 \mathrm{ppm}$ were made and measured for their absorbance with a UV-Vis spectrophotometer at a wavelength of $463 \mathrm{~nm}$ to obtain a standard curve of methyl orange absorption. The photocatalytic process was carried out in a photocatalysis reactor. A total of 0.1 gram of the synthesized $\mathrm{Bi}_{2} \mathrm{O}_{3}$ was added into $50 \mathrm{~mL}$ of $\mathrm{MO}$ solution. The mixture was then stirred using a magnetic stirrer at a speed of $667 \mathrm{rpm}$. The stirring time was $2 \mathrm{~h}$ for the photocatalytic test without light. Meanwhile, for the photocatalytic test with light, time variations of $2,4,6,8$, and $10 \mathrm{~h}$ were used. Light irradiation was carried out using a UV-A lamp (315-400 nm) with a power of 15 watts. The final step was measurement of the methyl orange absorbance of the solutions that had been treated without and with radiation at varying time duration using a UV-Vis spectrophotometer at a wavelength of $463 \mathrm{~nm}$.

\section{Results and Discussion}

\subsection{Synthesized Bismuth Oxide}

Bismuth oxide was synthesized using the hydrothermal method with time variations. The experiment aims to determine the effect of variations in hydrothermal time on the characteristics of the synthesized product. The hydrothermal time is said to affect the purity, crystal system, morphology, and crystal size, as well as the bandgap of the resulting product [26].

The synthesis was initiated by dissolving bismuth nitrate pentahydrate $\left(\mathrm{Bi}\left(\mathrm{NO}_{3}\right)_{3} .5 \mathrm{H}_{2} \mathrm{O}\right)$ and sodium sulfate $\left(\mathrm{Na}_{2} \mathrm{SO}_{4}\right)$ in distilled water then stirring them until homogenous. $\mathrm{Na}_{2} \mathrm{SO}_{4}$ would react with $\mathrm{Bi}\left(\mathrm{NO}_{3}\right)_{3} .5 \mathrm{H}_{2} \mathrm{O}$ to form $\mathrm{Bi}_{2} \mathrm{O}(\mathrm{OH})_{2} \mathrm{SO}_{4}$ complex, generating a product smaller in size than its precursors [14]. From the reaction of $\mathrm{Bi}\left(\mathrm{NO}_{3}\right)_{3} .5 \mathrm{H}_{2} \mathrm{O}$ and $\mathrm{Na}_{2} \mathrm{SO}_{4}$, a white suspension was obtained. After the formation of the white suspension, $\mathrm{NaOH}$ was added. The $\mathrm{OH}^{-}$ion from $\mathrm{NaOH}$ would react with $\mathrm{Bi}_{2} \mathrm{O}(\mathrm{OH})_{2} \mathrm{SO}_{4}$ to form a white precipitate of $\mathrm{Bi}(\mathrm{OH})_{3}$. The reaction mechanism that occurred is as follows:

$$
\begin{gathered}
2 \mathrm{Bi}\left(\mathrm{NO}_{3}\right)_{3} .5 \mathrm{H}_{2} \mathrm{O}+\mathrm{Na}_{2} \mathrm{SO}_{4} \rightarrow \mathrm{Bi}_{2} \mathrm{O}(\mathrm{OH})_{2} \mathrm{SO}_{4} \\
+2 \mathrm{NaNO}_{3}+4 \mathrm{HNO}_{3}+7 \mathrm{H}_{2} \mathrm{O} \\
\mathrm{Bi}_{2} \mathrm{O}(\mathrm{OH})_{2} \mathrm{SO}_{4}+2 \mathrm{NaOH}_{2}+\mathrm{H}_{2} \mathrm{O} \rightarrow \\
2 \mathrm{Bi}(\mathrm{OH})_{3}+\mathrm{Na}_{2} \mathrm{SO}_{4}
\end{gathered}
$$

The white precipitate was then transferred into the Teflon-lined autoclave and then into the hydrothermal reactor to be heated at a temperature of $120{ }^{\circ} \mathrm{C}$ with time variations of $8,10,12,14$, and $16 \mathrm{~h}$. When $\mathrm{Bi}(\mathrm{OH})_{3}$ is heated in a hydrothermal reactor, the compound will dehydrate and turn into $\mathrm{Bi}_{2} \mathrm{O}_{3}$ [14]. Subsequently, the obtained product was dried using an oven to remove water molecules that were still present in the $\mathrm{Bi}_{2} \mathrm{O}_{3}$ solid. The reaction mechanism that occurred in the hydrothermal reactor is as follows [14].

$$
2 \mathrm{Bi}(\mathrm{OH})_{3} \rightarrow \mathrm{Bi}_{2} \mathrm{O}_{3}+3 \mathrm{H}_{2} \mathrm{O}
$$

The five products obtained were in the form of powder with the same pale-yellow color. The pale yellow color indicated the presence of bismuth oxide in the synthesized products as it is one of the physical characteristics of bismuth oxide. The percentages of the yield of bismuth oxide with the hydrothermal times of $8,10,12$, 14 , and 16 h were $81.7 \%, 84.4 \%, 87.6 \%, 85.1 \%$, and $82.1 \%$, respectively.

\subsection{Physicochemical and Electrical Properties}

The XRD diffractograms of the bismuth oxide with variations in heating time are shown

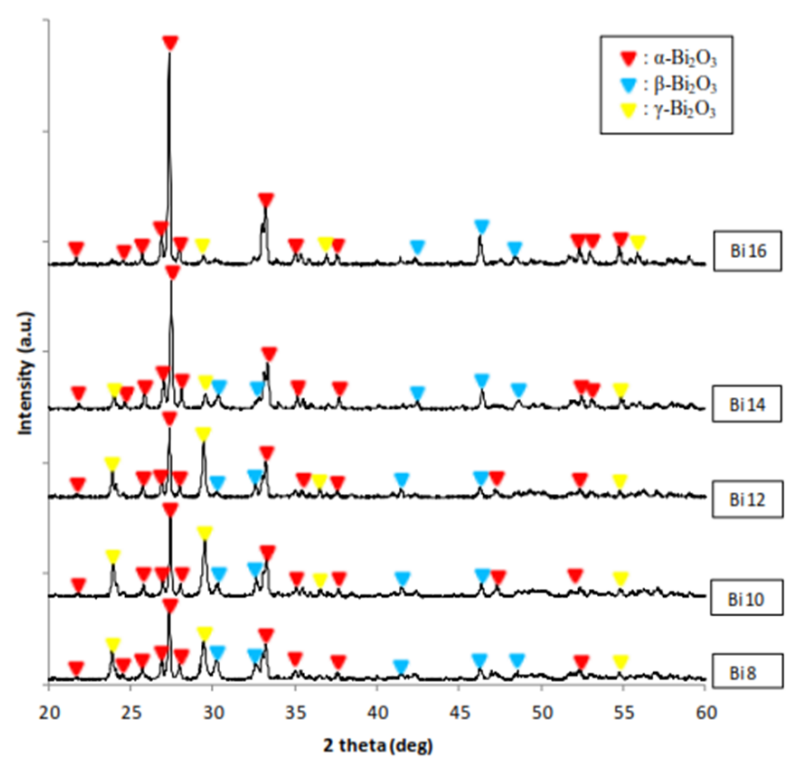

Figure 1. XRD diffractogram of bismuth oxide with variation in hydrothermal time. 
in Figure 1. XRD data interpretation was undertaken by fitting the $\mathrm{Bi}_{2} \mathrm{O}_{3}$ diffractogram peaks using the Origin Pro 8 software to identify the $2 \theta$ value precisely. The fitting data were then compared with the joint committee database on powder diffraction standards (JCPDS) to determine the sample crystal system.

Bismuth oxides with hydrothermal times of $8,10,12,14$, and $16 \mathrm{~h}$ possessed the same mixed crystal structure, namely $\alpha-\mathrm{Bi}_{2} \mathrm{O}_{3}$ (monoclinic), $\beta-\mathrm{Bi}_{2} \mathrm{O}_{3}$ (tetragonal), and $\gamma-\mathrm{Bi}_{2} \mathrm{O}_{3}$ (cubic). The $2 \theta$ data of the bismuth oxide synthesized are shown in Table 1. The data corresponded to the JCPDS database number 411449 for $\alpha-\mathrm{Bi}_{2} \mathrm{O}_{3}$, the JCPDS database number 27-0050 for $\beta-\mathrm{Bi}_{2} \mathrm{O}_{3}$, and the JCPDS database number 45-1344 for $\gamma-\mathrm{Bi}_{2} \mathrm{O}_{3}$.

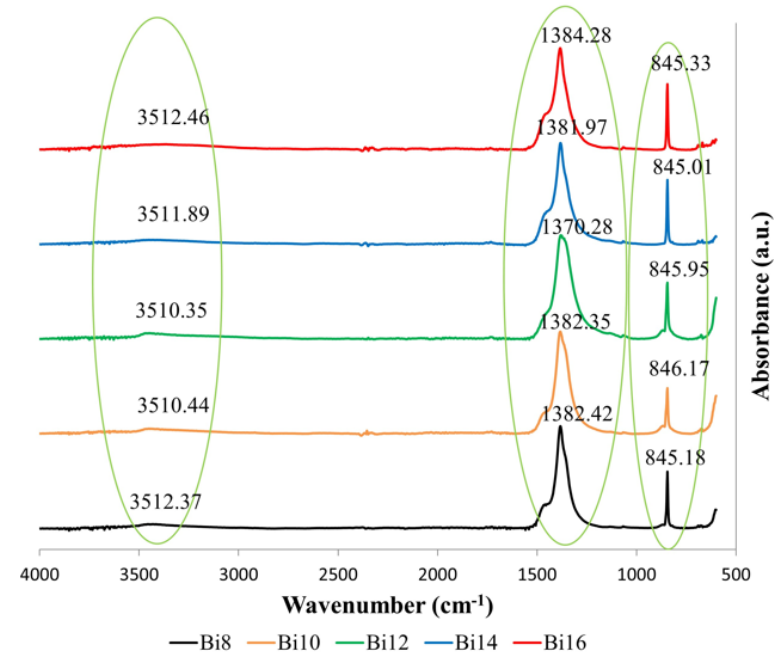

Figure 2. FTIR spectra of the synthesized bismuth oxide of varying hydrothermal times
As seen in Figure 1, the peak intensity ratios of $\alpha-\mathrm{Bi}_{2} \mathrm{O}_{3}$ to $\gamma-\mathrm{Bi}_{2} \mathrm{O}_{3}$ of the five samples were all different. The highest peak intensity ratio of $\alpha-\mathrm{Bi}_{2} \mathrm{O}_{3}$ to $\gamma-\mathrm{Bi}_{2} \mathrm{O}_{3}$ was found in $\mathrm{Bi}_{2} \mathrm{O}_{3}(16 \mathrm{~h})$, while the lowest was in $\mathrm{Bi}_{2} \mathrm{O}_{3}(12 \mathrm{~h})$. The higher peak ratio of $\alpha-\mathrm{Bi}_{2} \mathrm{O}_{3}$ to $\gamma-\mathrm{Bi}_{2} \mathrm{O}_{3}$ indicates that the intensity of the monoclinic crystal system $\left(\alpha-\mathrm{Bi}_{2} \mathrm{O}_{3}\right)$ contained in a sample is higher, while the intensity of the cubic crystal system $\left(\gamma-\mathrm{Bi}_{2} \mathrm{O}_{3}\right)$ is lower. This implied that $\mathrm{Bi}_{2} \mathrm{O}_{3}(16$ h) had the highest number of monoclinic crystal systems $\left(\alpha-\mathrm{Bi}_{2} \mathrm{O}_{3}\right)$ compared to the other hydrothermal time variations. Alternatively, $\mathrm{Bi}_{2} \mathrm{O}_{3}(12 \mathrm{~h})$ had the lowest number of monoclinic crystal systems, though, this also indicated that $\mathrm{Bi}_{2} \mathrm{O}_{3}(12 \mathrm{~h})$ had the highest number of cubic crystalline system $\left(\gamma-\mathrm{Bi}_{2} \mathrm{O}_{3}\right)$ compared to other $\mathrm{Bi}_{2} \mathrm{O}_{3}$. In the five-bismuth oxide diffractograms, it was also seen that the diffractogram peaks matched most with the JCPDS database of $\alpha-\mathrm{Bi}_{2} \mathrm{O}_{3}$ indicating that in the five bismuth oxide samples synthesized, the crystal system that was most abundant in the sample was the monoclinic crystal system of $\alpha-\mathrm{Bi}_{2} \mathrm{O}_{3}$.

From FTIR analysis, the five $\mathrm{Bi}_{2} \mathrm{O}_{3}$ samples obtained absorption peaks of the same functional groups though with different intensities. The FTIR spectra of the synthesized $\mathrm{Bi}_{2} \mathrm{O}_{3}$ are shown in Figure 2. The presence of absorptions at the wavenumber $845 \mathrm{~cm}^{-1}$ indicated the presence of a $\mathrm{Bi}-\mathrm{O}-\mathrm{Bi}$ group in the product [27] and at $1380 \mathrm{~cm}^{-1}$, the presence of $\mathrm{Bi}-\mathrm{OH}$ group in the product [28]. This is evidenced by the finding of a small absorption at wavenumber $3500 \mathrm{~cm}^{-1}$ which indicates the presence of the $\mathrm{OH}$ group [28].

Table 1 . XRD $2 \theta$ data of the synthesized bismuth oxides.

\begin{tabular}{|c|c|c|c|}
\hline \multirow{3}{*}{ Sample Code } & \multicolumn{3}{|c|}{ Crystal Phase } \\
\hline & $\alpha-\mathrm{Bi}_{2} \mathrm{O}_{3}$ & $\beta-\mathrm{Bi}_{2} \mathrm{O}_{3}$ & $\gamma-\mathrm{Bi}_{2} \mathrm{O}_{3}$ \\
\hline & $2 \theta(\circ)$ & $2 \theta(\mathrm{o})$ & $2 \theta(0)$ \\
\hline \multirow{3}{*}{$\mathrm{Bi} 8$} & 26.88 & 30.22 & 23.87 \\
\hline & 27.35 & 32.66 & 29.44 \\
\hline & 33.21 & 46.29 & 54.77 \\
\hline \multirow{3}{*}{ Bi10 } & 26.95 & 30.25 & 23.94 \\
\hline & 27.42 & 32.65 & 29.51 \\
\hline & 33.28 & 46.34 & 36.57 \\
\hline \multirow{3}{*}{ Bi12 } & 26.89 & 32.58 & 23.88 \\
\hline & 27.37 & 41.48 & 29.45 \\
\hline & 33.23 & 46.29 & 36.50 \\
\hline \multirow{3}{*}{ Bi14 } & 27.01 & 30.32 & 23.99 \\
\hline & 27.48 & 42.45 & 29.56 \\
\hline & 33.33 & 46.42 & 54.87 \\
\hline \multirow{3}{*}{ Bi16 } & 26.88 & 42.32 & 29.43 \\
\hline & 27.34 & 46.29 & 36.92 \\
\hline & 33.21 & 48.83 & 54.74 \\
\hline
\end{tabular}


The wavenumber range of $1250-1500 \mathrm{~cm}^{-1}$, as presented in Figure 2, was assumed to represent several groups, such as $\mathrm{NO}_{3}^{-}, \mathrm{N}=\mathrm{O}$, $\mathrm{O}=\mathrm{S}=\mathrm{O}$, and $\mathrm{Bi}-\mathrm{OH}$, that concurrently absorbed the infrared radiation resulting in a wide and sharp absorption peak. These functional groups were theorized to have come from the by-products generated during the synthesis process. With due regard, deconvolution peaks were made with the fityk application using the Gaussian function. The deconvolution peaks of Bi8, Bi10, Bi12, Bi14 and Bi16 are shown in Figure 3.

Figure 3 shows the four peak components that formed the peak that had been deconvoluted. The peak component around $1409 \mathrm{~cm}^{-1}$
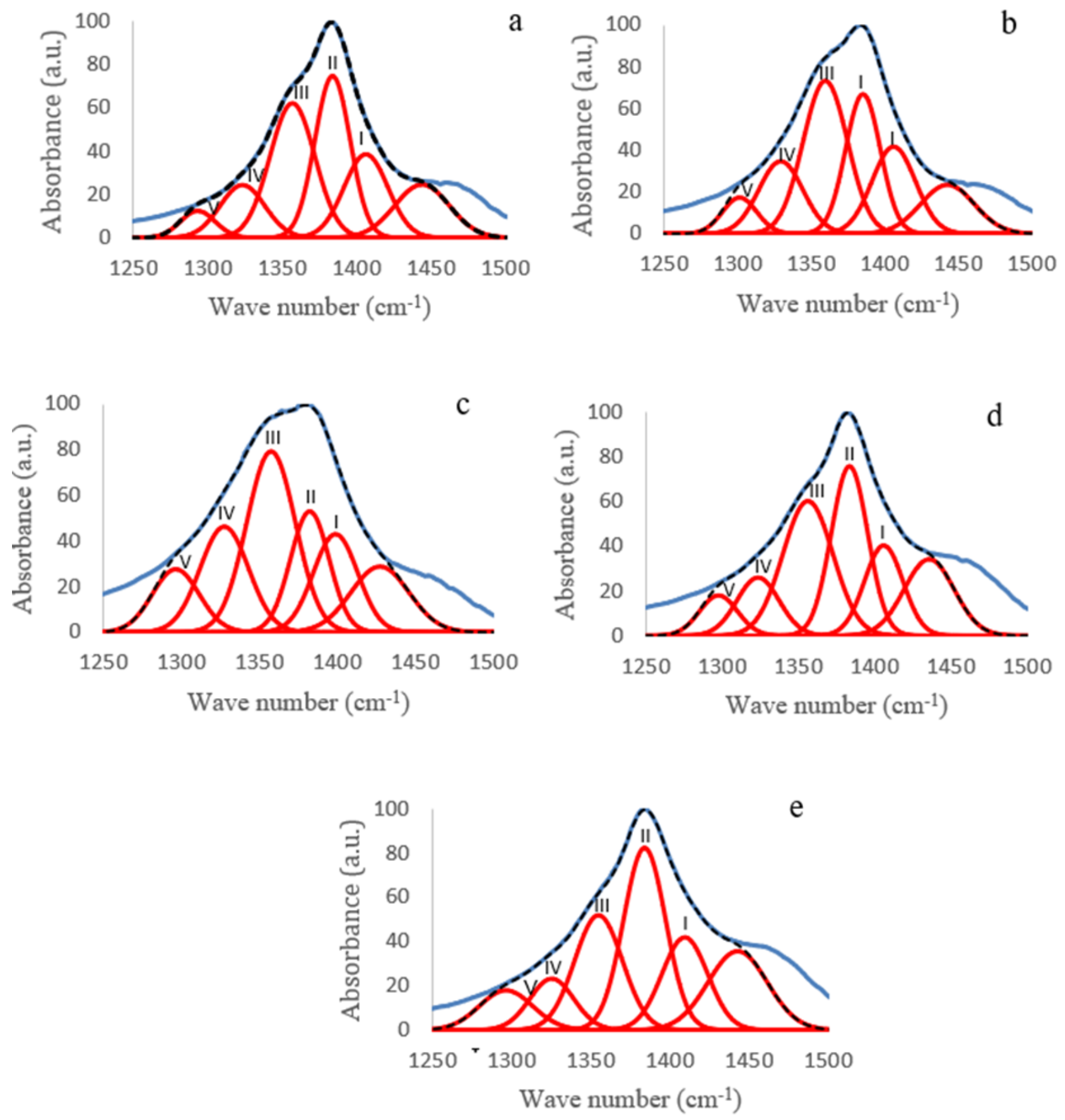

Experiment spectra

Peak components

Deconvoluted spectra

Figure 3. Deconvolution of FT-IR data of the synthesized bismuth oxide (a) Bi8; (b) Bi10; (c) Bi12; (d) Bi14; (e) Bi16. 
(I) indicated the stretching vibration of the $\mathrm{N}=\mathrm{O}$ group. Moreover, the component around $1325 \mathrm{~cm}^{-1}$ (IV) came from the asymmetric stretching vibration absorption of $\mathrm{O}=\mathrm{S}=\mathrm{O}$, whereas the wavenumber $1295 \mathrm{~cm}^{-1}$ (V) was from $\mathrm{NO}_{3}{ }^{-}$asymmetric stretching vibration absorption [29]. The peak component around $1380 \mathrm{~cm}^{-1}$ (II) was most likely the stretching vibration of the $\mathrm{Bi}-\mathrm{OH}$ group [28].

The presence of several functional groups such as $\mathrm{NO}_{3}{ }^{-}, \mathrm{N}=\mathrm{O}$ dan $\mathrm{O}=\mathrm{S}=\mathrm{O}$ might have originated from the by-products generated during the synthesis process. The peak component II, which indicated the presence of the $\mathrm{Bi}-\mathrm{OH}$ group, had the lowest intensity in bismuth oxide with a hydrothermal time of $12 \mathrm{~h}$. The $\mathrm{Bi}-\mathrm{OH}$ group most likely came from the $\mathrm{Bi}(\mathrm{OH})_{3}$ compound formed after the addition of $\mathrm{NaOH}$ during the synthesis process. These facts indicate that the $12 \mathrm{~h}$ sample had the highest $\mathrm{Bi}(\mathrm{OH})_{3}$ dehydration into $\mathrm{Bi}_{2} \mathrm{O}_{3}$ among other heating times.

In addition, the presence of peak component III at the wavenumber around $1380 \mathrm{~cm}^{-1}$ was a strong indication of the presence of the $\mathrm{Bi}-\mathrm{O}-\mathrm{Bi}$ group as evidenced by the FT-IR analysis of pure $\mathrm{Bi}_{2} \mathrm{O}_{3}$ from Sigma-Aldrich [13]. The
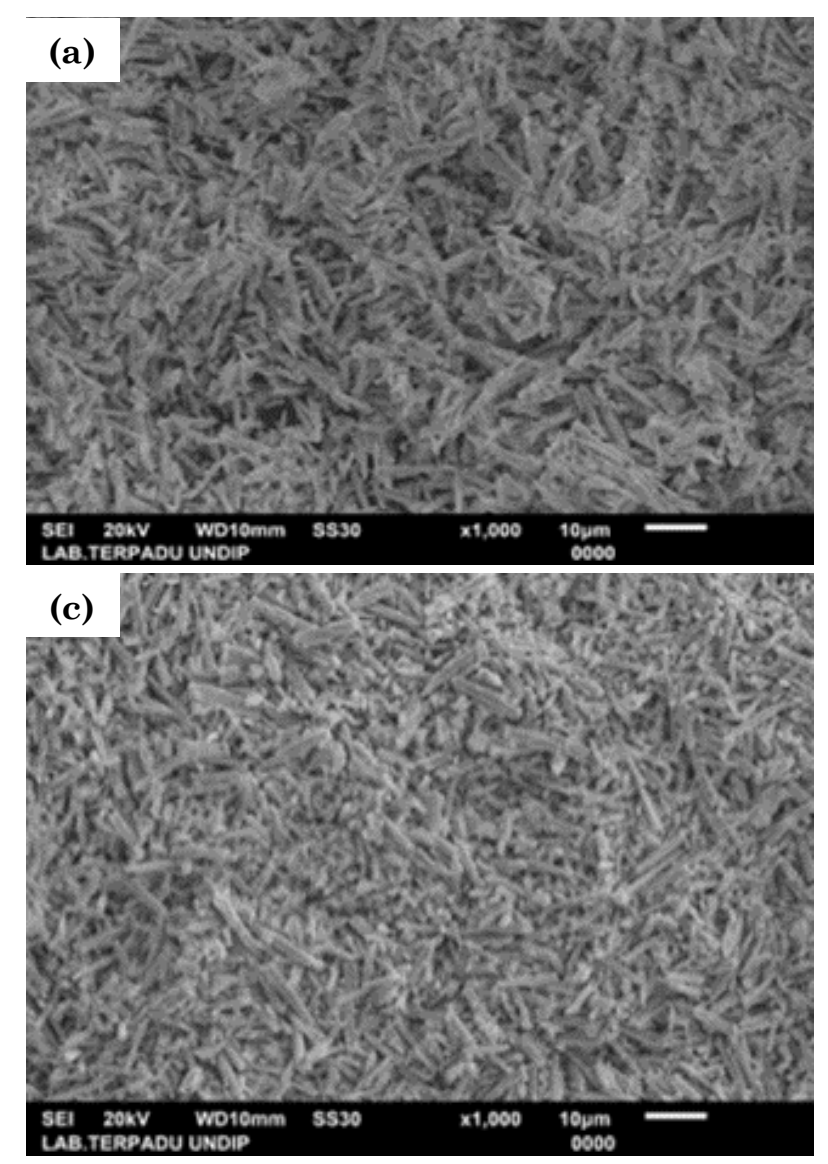

Figure 4. SEM images of bismuth oxide: (a) Bi12 at 1000x magnification; (b) Bi12 at 5000x magnification; (c) Bi16 at 1000x magnification; (d) Bi16 at 5000x magnification. highest intensity of peak component III was found in $\mathrm{Bi}_{2} \mathrm{O}_{3}$ with a hydrothermal time of 12 h.

The SEM analysis was carried out on products with the highest and lowest photocatalytic activity (see section 3.3), namely Bi12 and Bi16. The SEM images are shown in Figure 4. SEM images show that Bi12 and Bi16 have almost the same French fries-like shape. The lengths of the Bi12 and Bi16 were 5.3-8.3 $\mu \mathrm{m}$ and 7.1-10.3 $\mu \mathrm{m}$ and their widths were $0.6-1.2$

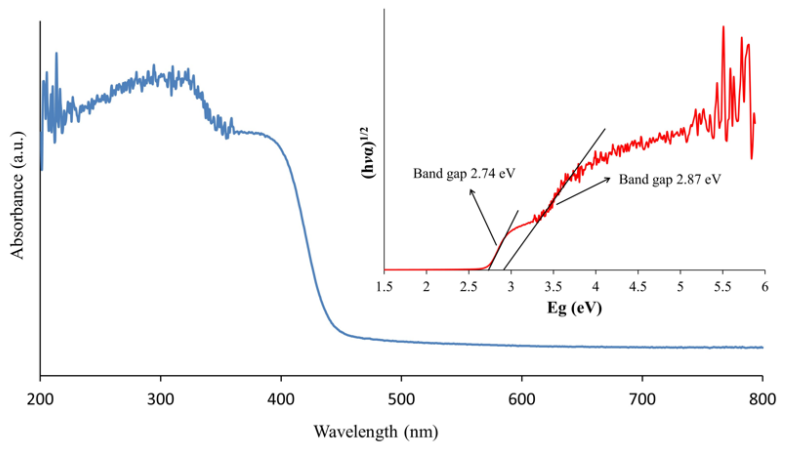

Figure 5. UV-DRS spectra of $\mathrm{Bi}_{2} \mathrm{O}_{3}$ with $12 \mathrm{~h}$ hydrothermal time.
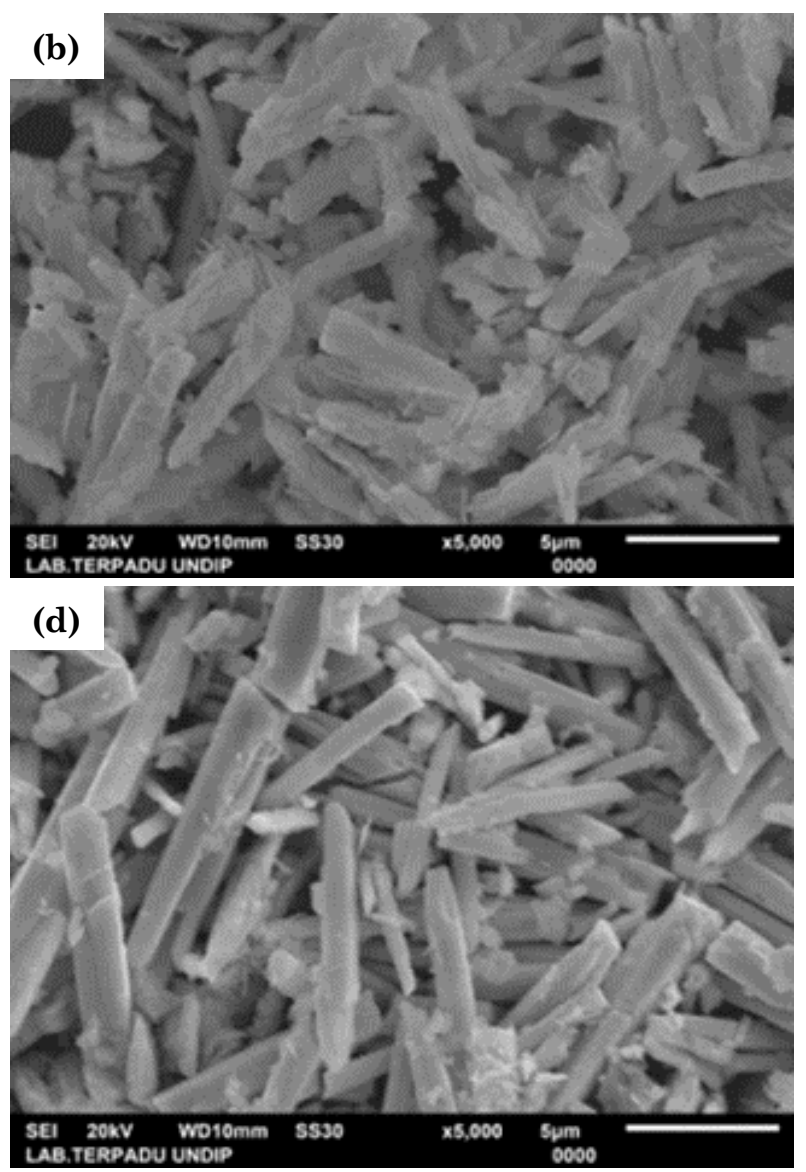
$\mu \mathrm{m}$ and $0.9-2.1 \mu \mathrm{m}$, respectively. Bi12 has a smaller particle size than Bi16. Particles with small sizes will have large surface areas, thus increasing the rate of photodegradation. This is consistent with the photocatalytic activity discussed in section 3.3 shown by Bi12 which has the highest activity among the samples.

The product bandgap with the highest photocatalyst activity, namely $\mathrm{Bi}_{2} \mathrm{O}_{3}(12 \mathrm{~h})$ was determined using UV-DRS. The UV-DRS spectra of bismuth oxide with a hydrothermal time of $12 \mathrm{~h}$ are shown in Figure 5. The bandgap values were obtained using the Tauc Plot calculation method [30]. This was done by making a graph of the relationship between $h v$ and $(h v \alpha)^{1 / 2}$ and drawing a straight line that runs across the inflection point on the curve and intersects the energy axis. The $\mathrm{x}$-axis represents the band $\left(E_{g}\right)$ in units of $\mathrm{eV}$, while the y-axis represents the value of $(h v \alpha)^{1 / 2}$. The Tauc equation is expressed in Equation (5).

$$
(h v \alpha)^{1 / n}=A\left(h v-E_{g}\right)
$$

where, $h=$ Planck's constant, $v=$ frequency, $E_{g}$ = bandgap, and $A=$ constant of proportionality. The exponential value $n$ shows the nature of the sample transition.

The gridline that intersects the $\mathrm{x}$-axis pointed out the band gap value of the bismuth oxide synthesized. Bi12 has two band gap values, namely $2.74 \mathrm{eV}$ and $2.87 \mathrm{eV}$. The two band gap

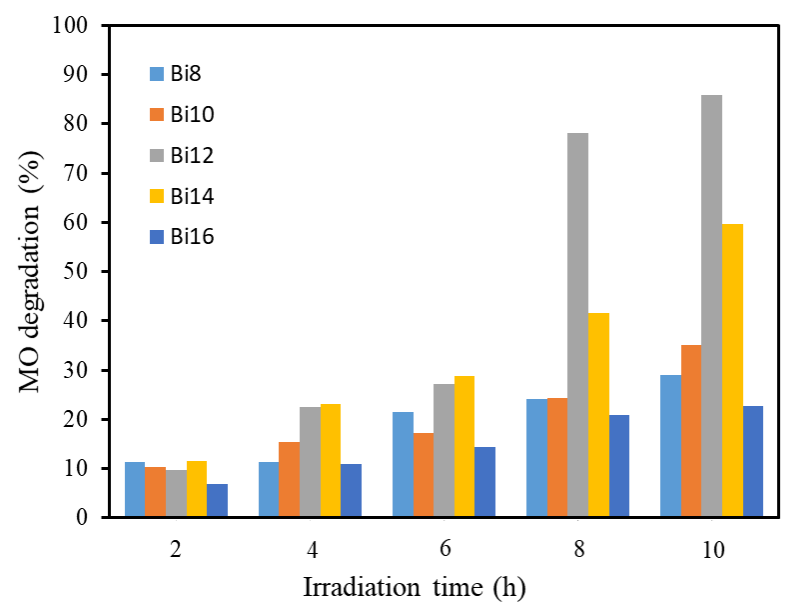

Figure 6. Graph of the effect of photocatalyst time on the percentage of MO degradation. values materialized because the synthesized $\mathrm{Bi}_{2} \mathrm{O}_{3}$ had a mixed crystal system, making it possible to have more than one band gap value. The bandgap values obtained also reinforced the fact that the bismuth oxide synthesized with a hydrothermal time of $12 \mathrm{~h}$ was mostly dominated by the monoclinic crystal system ( $\alpha$ $\mathrm{Bi}_{2} \mathrm{O}_{3}$ ) compared to other crystal structures in the sample since $\alpha-\mathrm{Bi}_{2} \mathrm{O}_{3}$ has a bandgap value of $2.85 \mathrm{eV}$ [11]. On the other hand, the bandgap value of $2.74 \mathrm{eV}$ further confirmed the presence of a cubic crystal system $\left(\gamma-\mathrm{Bi}_{2} \mathrm{O}_{3}\right)$ in the synthesized bismuth oxide, where $\gamma-\mathrm{Bi}_{2} \mathrm{O}_{3}$ has a bandgap of $2.783 \mathrm{eV}$ [31].

Furthermore, the electrical conductivity of bismuth oxide prepared by hydrothermal method can be seen in Table 2. Compared to bismuth oxide prepared with other methods, hydrothermal method results in bismuth oxide with the highest electrical conductivity. The high electrical conductivity presumably related with the morphology of the particles in which French-fries like shape is like wire $[32,33]$.

\subsection{Photocatalytic Activity of Bismuth Oxide}

The synthesized bismuth oxides were tested for their photocatalytic activity in degrading the methyl orange solution under ultraviolet light using a UV-A lamp (352 $\mathrm{nm})$ with a time of 2-10 h. The MO solution used for the photocatalytic test had a concentration of $5 \mathrm{ppm}$ and a volume of $50 \mathrm{~mL}$ for each variation of the test time. The absorbance of the degraded methyl orange solution was measured using a UV-Vis spectrophotometer at an optimum wavelength of $463 \mathrm{~nm}$. The graph of the percentage degradation of methyl orange against photocatalytic time on the percentage is shown in Figure 6.

Figure 6 shows that at the $2 \mathrm{~h}$ test time, the five samples had relatively the same percentages of degradation. At the test time of 4 and 6 $h$, significant differences in the percentages of degradation were starting to be seen in the five samples. At $4 \mathrm{~h}$, the percentage degradation of MO by Bi8, Bi10, Bi12, Bi14, and Bi16 were $11.25 \%, 15.31 \%, 22.50 \%, 23.13 \%$, and $10.94 \%$, respectively. Whereas at the $6 \mathrm{~h}$ time, the percentage of MO degradation by Bi8, Bi10, Bi12, Bi14, and Bi16 were 21.56\%, 17.19\%, 27.19\%,

Table 2. Electrical properties of bismuth oxide prepared by different methods.

\begin{tabular}{clc}
\hline No & Products & Electrical conductivity $\left({\left.\mathrm{S} . \mathrm{m}^{-1}\right)}^{-}\right.$ \\
\hline 1 & $\mathrm{Bi}_{2} \mathrm{O}_{3}$ prepared by hydrothermal & $1.565 \times 10^{-5}$ \\
2 & $\mathrm{Bi}_{2} \mathrm{O}_{3}$ prepared by sol gel [6] & $5.011 \times 10^{-7}$ \\
3 & $\mathrm{Bi}_{2} \mathrm{O}_{3}$ prepared by solution combustion [34] & $1.367 \times 10^{-7}$ \\
4 & Pure bismuth oxide from Sigma Aldrich & $1.556 \times 10^{-7}$ \\
\hline
\end{tabular}


$28.75 \%$, and $14.38 \%$, respectively. The percentage of MO degradation by bismuth oxide exhibited very significant differences at the test times of $8 \mathrm{~h}$ and $10 \mathrm{~h}$. In the photocatalyst test with a time of $8 \mathrm{~h}$, the percentage of MO degradation by $\mathrm{Bi} 8, \mathrm{Bi} 10, \mathrm{Bi} 12$, Bi14, Bi16 were $24.06 \%, 24.38 \%$, $78.13 \%$, $41.56 \%$, and $20.94 \%$, respectively. Whereas in the photocatalyst test with a time of $10 \mathrm{~h}$, the percentage of MO degradation by $\mathrm{Bi} 8$, Bi10, Bi12, Bi14, Bi16 were $29.06 \%, 35.00 \%, 85.94 \%, 59.69 \%$, and $22.81 \%$.

Based on the above data, the bismuth oxide which had the best photocatalytic activity was Bi12. Additionally, the photocatalytic test shows presented that optimal photodegradation can be obtained at $10 \mathrm{~h}$ photocatalytic time. Bi12 has the highest photocatalytic activity in degrading the methyl orange compound. This is in accordance with the FTIR data, where the bismuth oxide with the heating time of $12 \mathrm{~h}$ had the smallest absorption intensity of $\mathrm{Bi}-\mathrm{OH}$ groups, meaning that the amount of $\mathrm{Bi}(\mathrm{OH})_{3}$ dehydrated into $\mathrm{Bi}_{2} \mathrm{O}_{3}$ was largest among other heating time variations. Also, XRD analysis data showed that $\mathrm{Bi} 12$ was predominated by the monoclinic crystal system $\left(\alpha-\mathrm{Bi}_{2} \mathrm{O}_{3}\right)$ compared to other crystal systems. Furthermore, the cubic crystal system $\left(\gamma-\mathrm{Bi}_{2} \mathrm{O}_{3}\right)$ in $\mathrm{Bi} 12$ was highest in content when compared to $\mathrm{Bi}_{2} \mathrm{O}_{3}$ with other hydrothermal times. The data is also consistent with the UV-DRS analysis data in which bismuth oxide with the hydrothermal time of $12 \mathrm{~h}$ had two band gap values, namely $2.87 \mathrm{eV}$, which corresponds to the bandgap of $\alpha-\mathrm{Bi}_{2} \mathrm{O}_{3}$ [11] and $2.74 \mathrm{eV}$, which corresponds to the bandgap of $\gamma-\mathrm{Bi}_{2} \mathrm{O}_{3}$ [31]. The number of cubic crystal systems $\left(\gamma-\mathrm{Bi}_{2} \mathrm{O}_{3}\right)$ which was highest compared to the other time variations is also in line with the fact that Bi12 had the highest photocatalytic activity. This can be attributed to the fact that $\gamma-\mathrm{Bi}_{2} \mathrm{O}_{3}$ has a smaller bandgap than $\alpha-\mathrm{Bi}_{2} \mathrm{O}_{3}$. The smaller the band gap value, the better the photocatalytic process will be, because the electrons in the semiconductor will be more easily excited into the conduction band to form electron-hole pairs [35]. In addition, SEM results (see Figure 4) show that Bi12 has a relatively small particle size. When a material has a small particle size, then the material has a large surface area.

The mechanism of degradation of methyl orange (MO) by bismuth oxide that occurred is as follows:

$$
\begin{aligned}
& \mathrm{Bi}_{2} \mathrm{O}_{3}+\mathrm{h} v \rightarrow \mathrm{Bi}_{2} \mathrm{O}_{3}+\mathrm{e}^{-}+\mathrm{h}^{+} \\
& \mathrm{OH}+\mathrm{h}^{+} \rightarrow \cdot \mathrm{OH} \\
& \mathrm{H}_{2} \mathrm{O}+\mathrm{h}^{+} \rightarrow \cdot \cdot \mathrm{OH}+\mathrm{H}^{+} \\
& \mathrm{O}_{2}+\mathrm{e}^{-} \rightarrow \cdot \mathrm{O}_{2}^{-} \\
& \cdot \mathrm{O}_{2}++\mathrm{H}^{+} \rightarrow \mathrm{HO}_{2} \cdot \\
& 2 \mathrm{HO}_{2} \cdot \rightarrow \mathrm{O}_{2}+\mathrm{H}_{2} \mathrm{O}_{2} \\
& \mathrm{H}_{2} \mathrm{O}_{2}+\cdot \cdot \mathrm{O}_{2} \rightarrow \cdot \cdot \mathrm{OH}+\mathrm{OH}+\mathrm{O}_{2} \\
& \mathrm{MO}+\cdot \cdot \mathrm{OH}+\cdot \mathrm{O}_{2} \rightarrow \mathrm{CO}_{2}+\mathrm{H}_{2} \mathrm{O}+\mathrm{H}_{2} \mathrm{SO}_{4}+ \\
& \mathrm{NH}_{2} \mathrm{OH}+\mathrm{Bi}_{2} \mathrm{O}_{3}
\end{aligned}
$$

When the $\mathrm{Bi}_{2} \mathrm{O}_{3}$ semiconductor was illuminated by light, the electrons in the valence band would be excited towards the conduction band. This resulted in the formation of hole and electron pairs. Furthermore, $\cdot \mathrm{OH}$ originating from the water or water molecules adsorbed onto the surface of the $\mathrm{Bi}_{2} \mathrm{O}_{3}$ semiconductor would react with the holes to form $\cdot \mathrm{OH}$ and $\mathrm{H}^{+}$. The electrons in the conduction band would react with atmospheric $\mathrm{O}_{2}$ to form $\cdot \mathrm{O}_{2}$. The $\cdot \mathrm{O}_{2}$ could also
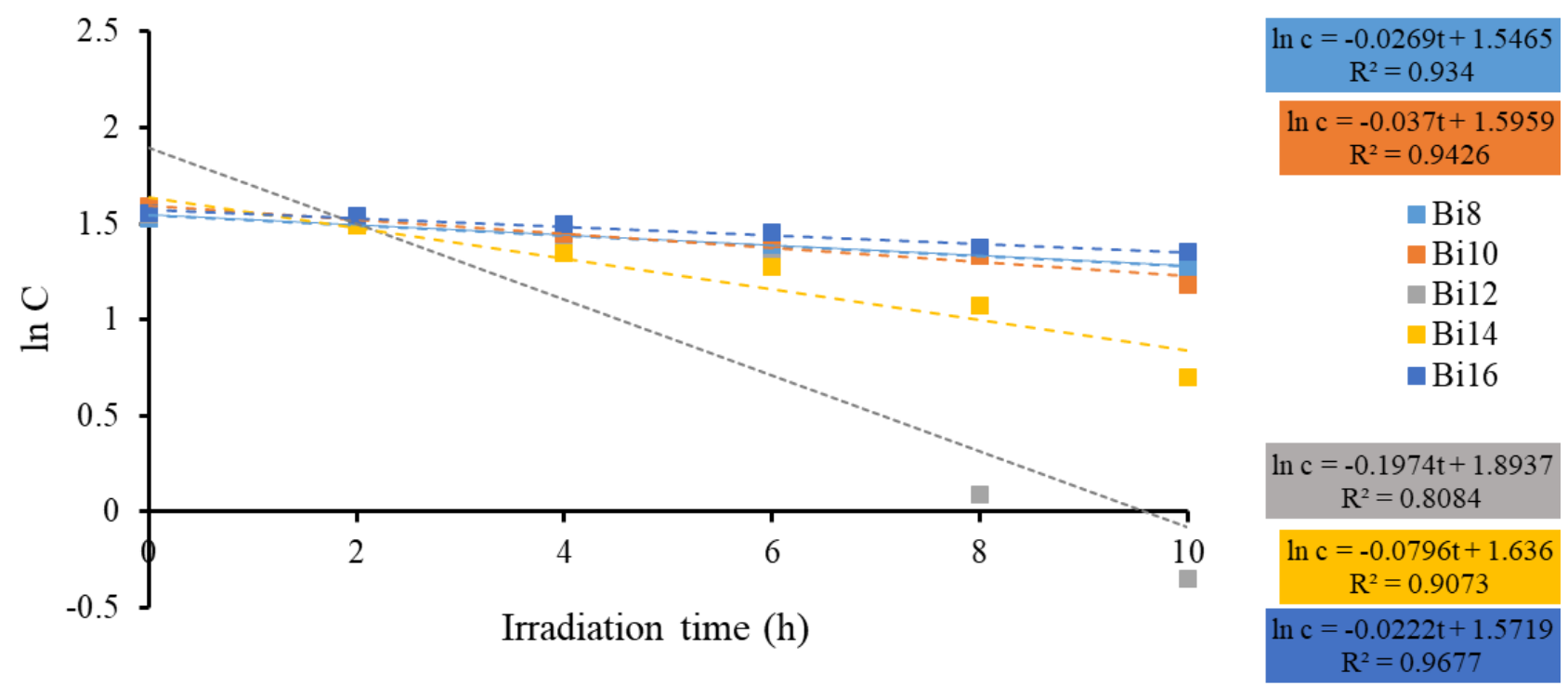

Figure 7. First-order reaction graph for the degradation of methyl orange. 
serve as a source in the formation of $\cdot \mathrm{OH}$ through a protonation process. The $\cdot \mathrm{OH}$ formed would then oxidize the methyl orange molecule into simpler compounds, namely $\mathrm{CO}_{2}$ and $\mathrm{H}_{2} \mathrm{O}$ [36].

Dye degradation reactions generally follow the first-order reaction kinetics which is stated as follows [37]:

$$
\ln C_{t}=\ln C_{0}-k t
$$

where, $k=$ constant rate of the first order reaction $\left(\mathrm{s}^{-1}\right), C_{0}=$ initial concentration of methyl orange solution (ppm), and $C_{t}=$ concentration of methyl orange solution (ppm) at time $t$. The first-order reaction graph for the degradation of methyl orange dye by bismuth oxide synthesized is shown in Figure 7. The slope value of the line equation obtained in the graph implied the rate constant value of the methyl orange degradation reaction. Based on the graph, the rate constants of the degradation reaction of methyl orange by $\mathrm{Bi} 8, \mathrm{Bi} 10, \mathrm{Bi} 12, \mathrm{Bi} 14$ and Bi16 were $8.38 \times 10^{-6} \mathrm{~s}^{-1}, \quad 1.05 \times 10^{-5} \mathrm{~s}^{-1}$, $6.92 \times 10^{-5} \mathrm{~s}^{-1}, 2.56 \times 10^{-5} \mathrm{~s}^{-1}$ and $6.86 \times 10^{-6} \mathrm{~s}^{-1}$. It can be seen that $\mathrm{Bi} 12$ has the largest rate constant for the degradation of methyl orange. This corresponds to the photocatalytic test results where Bi12 has the highest photocatalytic activity in the degradation of methyl orange.

\section{Conclusion}

The synthesis of bismuth oxide using the hydrothermal method has been successfully carried out and it was proven that variations in hydrothermal time affect the characteristics of the resulting product. The best product characteristics were obtained in the bismuth oxide with the hydrothermal time of $12 \mathrm{~h}$, shown by the results of FTIR analysis, where the $\mathrm{Bi}-\mathrm{O}-\mathrm{Bi}$ absorption in the sample was highest in intensity compared to others, and the SEM analysis results, which showed that the sample had a relatively small particle size (5.3-8.3 $\mu \mathrm{m})$. Moreover, compared to bismuth oxide synthesized using different method, hydrothermal method resulted in bismuth oxide with higher electrical conductivity. Based on the results of the photocatalytic activity test, the bismuth oxide with the hydrothermal time of $12 \mathrm{~h}$ had the largest degradation reaction rate constant compared to other samples, which was $6.92 \times 10^{-5}$ $\mathrm{s}^{-1}$.

\section{Acknowledgement}

The authors would like to thank Diponegoro University for financial support of the research through "Riset Publikasi Internasional (RPI)" scheme in fiscal year 2021 with the grant number 185-81/UN7.6.1/PP/2021.

\section{References}

[1] Ameta, R., Solanki, M.S., Benjamin, S., Ameta, S.C. (2018). Chapter 6 - Photocatalysis, in: Adv. Oxid. Process. Waste Water Treat.

[2] Li, Y., Trujillo, M.A., Fu, E., Patterson, B., Fei, L., Xu, Y., Deng, S., Smirnov, S., Luo, H. (2013). Bismuth oxide: A new lithium-ion battery anode. J. Mater. Chem. A., 1 (39), 1212312127. DOI: $10.1039 / \mathrm{c} 3$ ta $12655 \mathrm{~b}$.

[3] Jakubec, P., Malina, O., Tuček, J., Medř́ík, I., Medř́íková, Z., Slovák, P., Kašlík, J., Zbořil, R. (2019). Crystal Structure- and Morphology-Driven Electrochemistry of Iron Oxide Nanoparticles in Hydrogen Peroxide Detection. Adv. Mater. Interfaces., 6(3), 1801549. DOI: 10.1002/admi.201801549.

[4] Astuti, Y., Amri, D., Widodo, D.S., Widiyandari, H., Balgis, R., Ogi, T. (2020). Effect of fuels on the physicochemical properties and photocatalytic activity of bismuth oxide, synthesized using solution combustion method. Int. J. Technol., 11(1), 26-36. DOI: 10.14716/ijtech.v11i1.3342.

[5] Astuti, Y., Andianingrum, R., Arnelli, A., Haris, A., Darmawan, A. (2020). The Role of $\mathrm{H}_{2} \mathrm{C}_{2} \mathrm{O}_{4}$ and $\mathrm{Na}_{2} \mathrm{CO}_{3}$ as Precipitating Agents on the Physichochemical Properties and Photocatalytic Activity of Bismuth Oxide. Open Chem., 18(1), 129-137. DOI: 10.1515/chem2020-0013.

[6] Astuti, Y., Listyani, B.M., Suyati, L., Darmawan, A. (2021). Bismuth oxide prepared by sol-gel method: Variation of physicochemical characteristics and photocatalytic activity due to difference in calcination temperature. Indonesian J. Chem., 21(1), 108-117. DOI: 10.22146/ijc.53144.

[7] Pugazhenthiran, N., Sathishkumar, P., Murugesan, S., Anandan, S. (2011). Effective degradation of acid orange 10 by catalytic ozonation in the presence of $\mathrm{Au}-\mathrm{Bi}_{2} \mathrm{O}_{3}$ nanoparticles. Chem. Eng. J., 168(3), 1227-1233. DOI: 10.1016/j.cej.2011.02.020.

[8] Zhou, L., Wang, W., Xu, H., Sun, S., Shang, M. (2009). $\mathrm{Bi}_{2} \mathrm{O}_{3}$ hierarchical nanostructures: Controllable synthesis, growth mechanism, and their application in photocatalysis. Chem. - A Eur. J., 15(7), 1776-1782. DOI: 10.1002/chem.200801234. 
[9] Iyyapushpam, S., Nishanthi, S.T., Pathinettam Padiyan, D. (2014). Enhanced photocatalytic degradation of methyl orange by gamma $\mathrm{Bi}_{2} \mathrm{O}_{3}$ and its kinetics. J. Alloys Compd., 601(2014), 85-87. DOI: 10.1016/j.jallcom.2014.02.142.

[10] Moyseowicz, A., Moyseowicz, A. (2020). Tailoring the morphology, crystalline structure, and electrochemical properties of nanostructured $\mathrm{Bi}_{2} \mathrm{~S}_{3}$ using various solvent mixtures. Mater. Renew. Sustain. Energy., 9 (2020), 110. DOI: $10.1007 / \mathrm{s} 40243-020-00171-9$.

[11] Hernandez-Delgadillo, R., Velasco-Arias, D., Martinez-Sanmiguel, J.J., Diaz, D., ZumetaDube, I., Arevalo-Niño, K., Cabral-Romero, C. (2013). Bismuth oxide aqueous colloidal nanoparticles inhibit Candida albicans growth and biofilm formation. Int. J. Nanomedicine., 8 (2013), 1645-1652. DOI: 10.2147/IJN.S38708.

[12] Astuti, Y., Fauziyah, A., Widiyandari, H., Widodo, D.S. (2019). Studying impact of citric acid-bismuth nitrate pentahydrate ratio on photocatalytic activity of bismuth oxide prepared by solution combustion method. $R a$ sayan J. Chem., 12(4), 2210-2217. DOI: 10.31788/RJC.2019.1245323.

[13] Astuti, Y., Elesta, P.P., Widodo, D.S., Widiyandari, H., Balgis, R. (2020). Hydrazine and urea fueled-solution combustion method for $\mathrm{Bi}_{2} \mathrm{O}_{3}$ synthesis: Characterization of physicochemical properties and photocatalytic activity. Bull. Chem. React. Eng. Catal., 15(1), 104111. DOI: 10.9767/bcrec.15.1.5483.104-111.

[14] Wu, C., Shen, L., Huang, Q., Zhang, Y.C. (2011). Hydrothermal synthesis and characterization of $\mathrm{Bi}_{2} \mathrm{O}_{3}$ nanowires. Mater. Lett., 65 ( 7 ), $1134-1136$. D O I : 10.1016/j.matlet.2011.01.021.

[15] Zulkifli, Z.A., Razak, K.A., Rahman, W.N.W.A., Abidin, S.Z. (2018). Synthesis and Characterisation of Bismuth Oxide Nanoparticles using Hydrothermal Method: The Effect of Reactant Concentrations and application in radiotherapy. J. Phys. Conf. Ser., 1082, 012103-1-6. DOI: 10.1088/1742. 6596/1082/1/012103.

[16] Zulkifli, Z.A., Razak, K.A., Rahman, W.N.W.A. (2018). The effect of reaction temperature on the particle size of bismuth oxide nanoparticles synthesized via hydrothermal method. AIP Conf. Proc., 1958, 020007-1020007-1-7. DOI: 10.1063/1.5034538.

[17] Zulkifli, Z.A., Razak, K.A., Rahman, W.N.W.A. (2017). Effect of hydrothermal reaction time on size of bismuth oxide nanoparticles synthesized via hydrothermal method. AIP Conf. Proc., 1901, 020011-1-020011-6. DOI: $10.1063 / 1.5010448$.
[18] Yang, Q., Li, Y., Yin, Q., Wang, P., Cheng, Y.B. (2002). Hydrothermal synthesis of bismuth oxide needles. Mater. Lett., 55(1-2), 4649. DOI: 10.1016/S0167-577X(01)00617-6.

[19] Behzad, M., Sabaghian, M., Jahromi, H.S. (2015). Alfa- Bismuth(III)oxide catalyzed Biginelli reactions using experimentally designed optimized condition. J. Adv. Mater. Process., 3(4), 61-69. Retrieved from: http://jmatpro.iaun.ac.ir/article_562063.html.

[20] Astuti, Y., Arnelli, A., Pardoyo, P., Fauziyah, A., Nurhayati, S., Wulansari, A.D., Andianingrum, R., Widiyandari, H., Bhaduri, G.A. (2017). Studying impact of different precipitating agents on crystal structure, morphology and photocatalytic activity of bismuth oxide. Bull. Chem. React. Eng. Catal., 12 ( 3 ), $478-484$. D O I : 10.9767/bcrec.12.3.1144.478-484.

[21] Astuti, Y., Anggraeni, D., Darmawan, A. (2020). Photocatalytic Performance of Bismuth Oxide Prepared by Citric Acid-Fueled Solution Combustion on Decolorisation of Organic Dye Molecules. IOP Conf. Ser. Mater. Sci. Eng., 833, 012061-1-6. DOI: 10.1088/1757-899X/833/1/012061.

[22] Khataee, A., Alidokht, L., Hassani, A., Karaca, S. (2013). Response surface analysis of removal of a textile dye by a Turkish coal powder. Adv. Environ. Res., 2(4), 291-308. DOI: 10.12989/aer.2013.2.4.291.

[23] Hassani, A., Faraji, M., Eghbali, P. (2020). Facile fabrication of mpg- $\mathrm{C}_{3} \mathrm{~N}_{4} / \mathrm{Ag} / \mathrm{ZnO}$ nanowires/Zn photocatalyst plates for photodegradation of dye pollutant. J. Photochem. Photobiol. A., 400(2020), 112665. DOI: 10.1016/j.jphotochem.2020.112665

[24] Hassani, A., Krishnan, S., Scaria, J., Eghbali, P., Nidheesh, P.V. (2021). Z-scheme photocatalysts for visible-light-driven pollutants degradation: A review on recent advancements. Curr. Opin. Solid State Mater. Sci., $25(5), \quad 100941-1-25$. D O I : 10.1016/j.cossms.2021.100941.

[25] Motlagh, P.Y., Khataee, A., Hassani, A., Rad, T.S. (2020). ZnFe-LDH/GO nanocomposite coated on the glass support as a highly efficient catalyst for visible light photodegradation of an emerging pollutant. J. Mol. Liq., $302(2020), \quad 112532-1-14$. DOI : 10.1016/j.molliq.2020.112532.

[26] Helal, A., Harraz, F.A., Ismail, A.A., Sami, T.M., Ibrahim, I.A. (2016). Controlled synthesis of bismuth sulfide nanorods by hydrothermal method and their photocatalytic activity. Mater. Des., 102(2016), 202-212. DOI: 10.1016/j.matdes.2016.04.043. 
[27] Li, W. (2006). Facile synthesis of monodisperse $\mathrm{Bi}_{2} \mathrm{O}_{3}$ nanoparticles. Mater. Chem. Phys., 99 (1), 174-180. DOI: 10.1016/j.matchemphys.2005.11.007.

[28] Bartonickova, E., Cihlar, J., Castkova, K. (2007). Microwave-assisted synthesis of bismuth oxide. Process. Appl. Ceram., 1(1-2), 2933. DOI: $10.2298 /$ pac0702029b.

[29] Colthup, N. (2012). Introduction to Infrared and Raman Spectroscopy - Norman Colthup Google Books, Deliv. Nanoparticles.

[30] Daniyati, R., Zharvan, V., Pramono, Y.H. (2015). Penentuan Energi Celah Pita Optik Film $\mathrm{TiO}_{2}$ Menggunakan Metode Tauc Plot. Pros. Semin. Sains dan Teknol., 1, 1-5

[31] Iyyapushpam, S., Nishanthi, S.T., Padiyan, D.P. (2015). Synthesis of $\beta-\mathrm{Bi}_{2} \mathrm{O}_{3}$ towards the application of photocatalytic degradation of methyl orange and its instability. J. Phys. Chem. Solids., 81, 74-78. DOI: 10.1016/j.jpcs.2015.02.005.

[32] Mahmoud, W.E., Al-Ghamdi, A.A. (2010). Electrical and mechanical properties of bismuth oxide nanowire/poly(vinyl acetate). J. Appl. Polym. Sci., 118(3), 1598-1605. DOI: 10.1002/app.32523.

[33] Goncharova, A.S., Napolskii, K.S., Skryabina, O.V., Stolyarov, V.S., Levin, E.E., Egorov, S.V., Eliseev, A.A., Kasumov, Y.A., Ryazanov, V.V., Tsirlina, G.A. (2020). Bismuth nanowires: Electrochemical fabrication, structural features, and transport properties. Phys. Chem. Chem. Phys., 22(26), 14953-14964. DOI: $10.1039 / \mathrm{d} 0 \mathrm{cp} 0111 \mathrm{~h}$.
[34] Astuti, Y., Fauziyah, A., Nurhayati, S., Wulansari, A.D., Andianingrum, R., Hakim, A.R., Bhaduri, G. (2016). Synthesis of aBismuth oxide using solution combustion method and its photocatalytic properties. IOP Conf. Ser. Mater. Sci. Eng., 107 (2016), 012006-1-7. DOI: $10.1088 / 1757$. $899 X / 107 / 1 / 012006$.

[35] Licciulli, A., Lisi, D. (2002). Self-cleaning glass, Univ. Degli Stud. Di Lecce.

[36] Liu, X., Deng, H., Yao, W., Jiang, Q., Shen, J. (2015). Preparation and photocatalytic activity of Y-doped $\mathrm{Bi}_{2} \mathrm{O}_{3}$. J. Alloys Compd., 651 $\left(\begin{array}{llll}2 & 0 & 1 & 5\end{array}\right), \quad 135-142$. D O I : 10.1016/j.jallcom.2015.08.068.

[37] Wang, Q., Hui, J., Yang, L., Huang, H., Cai, Y., Yin, S., Ding, Y. (2014). Enhanced photocatalytic performance of $\mathrm{Bi}_{2} \mathrm{O}_{3} / \mathrm{H}-\mathrm{ZSM}-5$ composite for rhodamine B degradation under UV light irradiation. Appl. Surf. Sci., 289, 224229. DOI: $10.1016 /$ j.apsusc.2013.10.139 